\title{
Axis screws: results and complications of a large case series
}

(D) Cleiton Formentin ${ }^{\mathbf{1}}$ (D) Erion Junior de Andrade ${ }^{1}$ (iD) Fernando Luis Maeda ${ }^{1}$ (iD) Enrico Ghizoni² (D) Helder Tedeschi (iD) Andrei F. Joaquim ${ }^{3}$

1. Resident - Neurosurgery Division - Department of Neurology, University of Campinas (UNICAMP), Campinas-SP, Brasil
2. Assistant Professor - Neurosurgery Division - University of Campinas (UNICAMP), Campinas-SP, Brasil 2. Assistant Professor - Neurosurgery Division - University of Campinas (UNICAMP), Campinas-SP, Brasil
3. Assistant Professor - Neurosurgery Division - University of Campinas (UNICAMP), Campinas-SP, Brasil.

http://dx.doi.org/10.1590/1806-9282.65.2.198

SUMMARY

OBJECTIVE: To present the surgical results of patients who underwent axis screw instrumentation, discussing surgical nuances and complications of the techniques used.

METHODS: Retrospective case-series evaluation of patients who underwent spinal surgery with axis instrumentation using screws.

RESULTS: Sixty-five patients were included in this study. The most common cause of mechanical instability was spinal cord trauma involving the axis (36 patients - 55.4\%), followed by congenital craniocervical malformation (12 patients - 18.5\%). Thirty-seven (57\%) patients required concomitant C1 fusion. Bilateral axis fixation was performed in almost all cases. Twenty-three patients (35.4\%) underwent bilateral laminar screws fixation; pars screws were used in twenty-two patients (33.8\%), and pedicular screws were used isolated in only three patients (4.6\%). In fourteen patients (21.5\%), we performed a hybrid construction. There was no neurological worsening nor vertebral artery injury in this series.

CONCLUSION: Axis screw instrumentation proved to be a safe and efficient method for cervical stabilization. Laminar and pars screws were the most commonly used

KEYWORDS: Axis, cervical vertebra. Cervical vertebrae. Bone screws. Internal fixators.

\section{INTRODUCTION}

The atlantoaxial complex has a unique bone, ligamentous, and vascular anatomy that particularly distinguishes it from the subaxial spine, making it challenging to achieve mechanical stability in this very mobile spine segment ${ }^{1-3}$. Due to the high range of motion of the C1-2 segment, fusion rates at this level have been lower than those at the subaxial spine $\mathrm{s}^{4-6}$.

Spinal diseases such as trauma, congenital malformations, tumors, and inflammatory disorders may lead to cervical instability involving the axis, 
requiring surgical fixation ${ }^{7,8}$. Although the posterior wiring procedure is easy to accomplish, this technique has a high rate of nonunion, leading to incomplete immobilization and pseudoarthrosis ${ }^{9-12}$.

Since the first description of the sublaminar wiring technique by Gallie ${ }^{6}$ in 1939, many derived procedures for internal fixation have been proposed to treat atlantoaxial instability ${ }^{4,13,14}$. Although the transarticular screw fixation provides superior stability and higher bone fusion rates compared to wiring ${ }^{12,15}$, it is a technically demanding procedure with a risk of injury to the vertebral artery and spinal cord ${ }^{16,17}$.

Pedicle screws fixation has emerged as an effective form of axis instrumentation and is probably the technique that offers the strongest possible fixation ${ }^{18,19}$. Another screw fixation technique, very similar to the transarticular C1-2 technique, is the insertion of pars interarticularis screws, using shorter length screws, with the same trajectory through the isthmus ${ }^{20}$. In patients who do not require a laminectomy and have a prohibitive pedicle or pars anatomy, the use of laminar screws for immobilization of the axis is possible and without risk of vertebral artery injury $^{20-22}$.

We have previously published our preliminary experience with axis screws instrumentation, proposing an algorithm on the decision for axis fixation ${ }^{23}$. In the present study, we present our experience with a more extensive series of cases of axis screw instrumentation, discussing surgical nuances and complications.

\section{METHODS}

A retrospective case series of patients who underwent axis stabilization using pars, pedicle, or laminar screws from 2009 to 2017 was performed by a single surgeon (AFJ). Forty-seven more patients were added to our previously published initial case series of 17 patients $^{23}$. All patients that underwent surgery that involved axis fixation with screws were included. The only exclusion criteria were lack of clinical or radiological data. The study was part of a database of spinal patients, performed retrospectively (17337313.7.0000.5404)

The collected clinical data included: age, sex, surgical indication, surgical complications and preand post-op neurological status. Radiological images were obtained preoperatively in all patients. 3D CT scans and CT angiogram (whenever assessment of the vertebral artery involvement was necessary) were analyzed by the chief surgeon (AFJ) in order to evaluate axis morphology and decide about the fixation technique to be used.

After the surgical procedure, all patients underwent at least one CT scan for checking screws position and plain radiographs with a dynamic image during follow-up.

\section{RESULTS}

Sixty-five patients with complete data were found in our database. Forty patients were male (61.5\%), and twenty-five were female (38.5\%). The average age was 42.2 years (ranging from 5 to 77 years old). The demographic data are presented in Table 1, and case examples are shown in figures 1 to 2 .

The majority of our cases were due to spinal trauma involving the axis (36 patients $-55.4 \%$ ), followed by congenital craniocervical malformations (twelve patients - 18.5\%), degenerative spine conditions (nine patients $-13.8 \%$ ), spinal tumors (two spinal metastases and one primary giant cell tumor $-4.6 \%$ ), post-laminectomy kyphosis (three patients $-4.6 \%$ ) and inflammatory disorders (two cases of rheumatoid arthritis leading to C1-2 instability - 3.1\%)

Thirty-seven patients (57\%) required concomitant C1 fusion and fourteen cases (21.5\%) underwent occipitocervical fusion.

Bilateral axis fixation was possible in the majority of cases (60 patients - 92.3\%). Twenty-three patients

TABLE 1. DEMOGRAPHIC DATA

\begin{tabular}{l|l|l} 
Variable & Median (range) & $\mathrm{n}(\%)$ \\
\hline Demographics & $42.2(5-77)$ & 35.4 \\
\hline Age & & $40(61.5)$ \\
\hline Male & & $25(38.5)$ \\
\hline Female & & \\
\hline Etiology & $36(55.4)$ \\
\hline Trauma & $12(18.5)$ \\
\hline Congenital malformation & & $9(13.8)$ \\
\hline Degenerative & & $3(4.6)$ \\
\hline Tumors & & $3(4.6)$ \\
\hline Post-laminectomy & & $2(3.1)$ \\
\hline Inflammatory disorders & & \\
\hline Concomitant fusion & & $14(21.5)$ \\
\hline C1-2 & & $14.5)$ \\
\hline Occipitocervical & & \\
\hline Subaxial & & \\
\hline
\end{tabular}




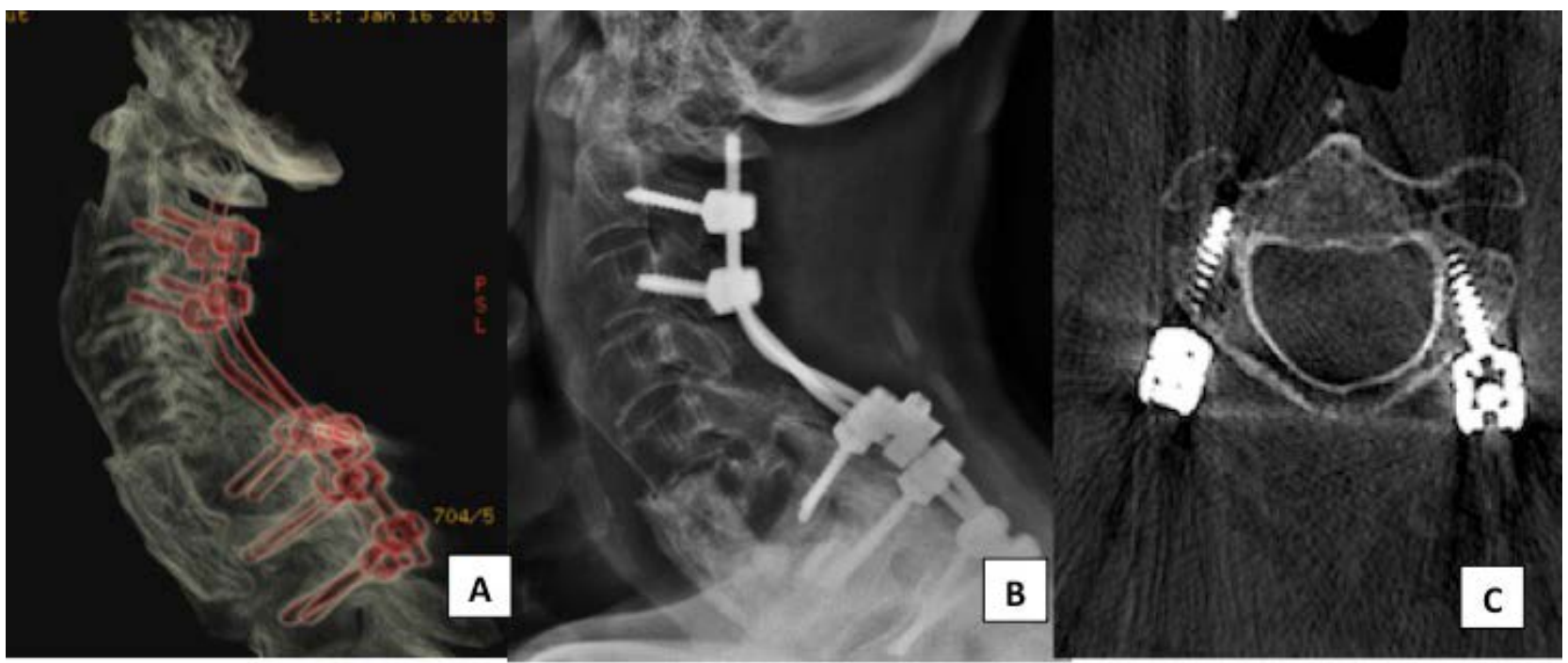

FIGURE 1. A cervico-thoracic fusion for treatment of a post-laminectomy defect. (A) Sagittal CT scan reconstruction, (B) postoperative lateral $\mathrm{X}$-ray and (C) axial CT scan showing a right C2 pars screw and a left C2 pedicular screw.
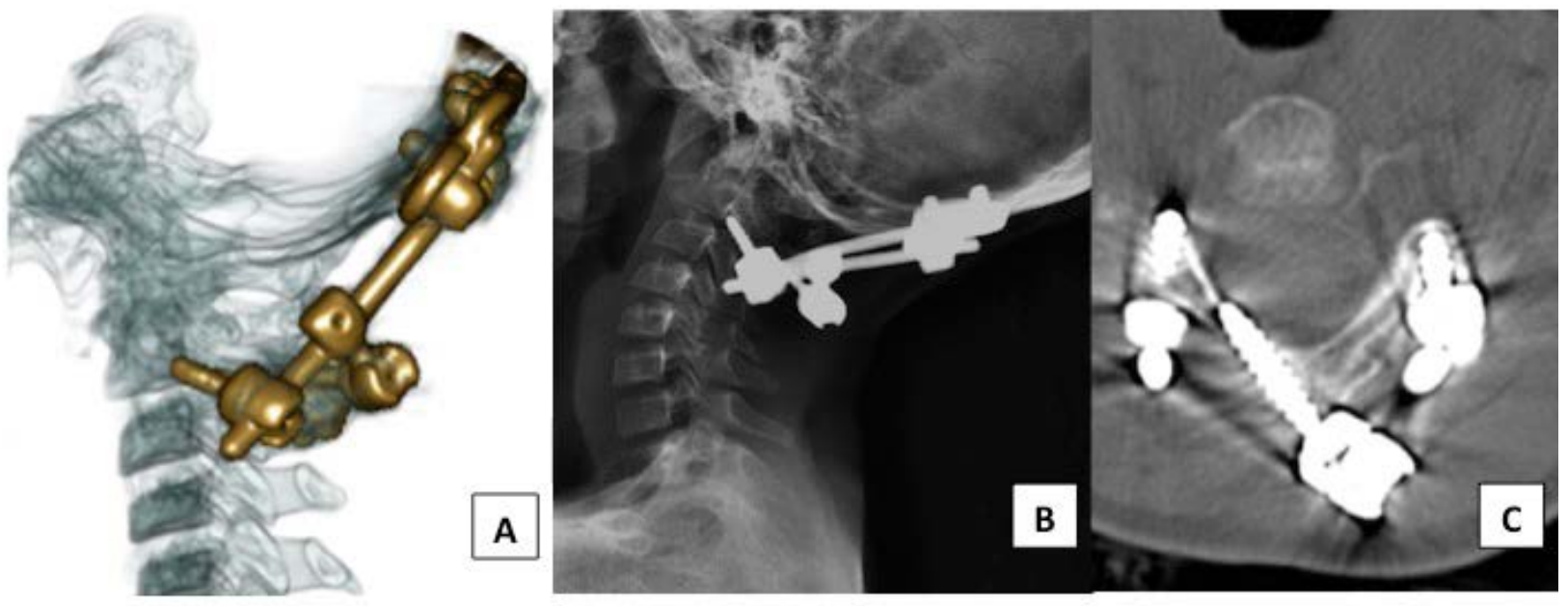

FIGURE 2. An occipitocervical fusion for treatment of a bone cyst of the atlas. (A) Sagittal CT scan reconstruction, (B) postoperative lateral extension cervical spine X-ray and (C) axial CT scan showing a right C2 laminar screw and bilateral C2 pars screws.

(35.4\%) underwent bilateral laminar screws fixation; pars screws were used in twenty-two cases (33.8\%), and pedicular screws were used in only three cases (4.6\%). In fourteen cases (21.5\%), we performed a screw hybrid construction: lamina and pars (eight cases), pedicle and pars (three cases), pedicle and lamina (one case), bilateral pars and lamina (one case) and bilateral lamina and pars (one case). In three cases, we had to use unilateral screw fixation: two with one laminar screw and one with pars screw.

Considering hybrid construction, two cases required three axis screws. In one of these patients, with complex axis fracture and C1-2 luxation, we used concomitant $\mathrm{C} 1$ lateral mass screw and C2 bilateral laminar and unilateral pars screws. In another patient, a child with a C1 bone cyst, we performed a hybrid construction with bilateral pars and unilateral laminar screws and a concomitant occipitocervical fusion. A total of 132 axis screws were used considering all the patients.

In one case, we had a superficial infection at the site where the graft was harvested. There was no neurological worsening or complications directly related to the use of axis screws, such as vertebral artery injury or neurologic injury. One patient (with a giant cell tumor and a C2-T2 fusion) had a pars screw pulled out during follow-up, but was not reoperated once she had only mild cervical pain. One patient with a C2 pedicle screw had a canal violation but was not reoperated either, since the patient was asymptomatic. 
There were no surgical related deaths in this series. One patient, with traumatic brain injury and Type II odontoid fracture, died from pulmonary sepsis one month after the procedure. The most common complication was superficial wound infection in three cases $(4.6 \%)$, all of them in occipitocervical fusions.

\section{DISCUSSION}

Although there are many techniques for screw fixation of $\mathrm{C} 2$ available, the unique anatomy of this vertebra and its variations can significantly impact all these procedures ${ }^{24}$. Therefore, solid anatomical knowledge and the surgeon's familiarity with C2 screw fixation techniques are of paramount importance for the efficacy of the procedure.

Transarticular screws are widely used and described in the literature for their superiority in biomechanical immobilization of $\mathrm{C} 1-2^{5}$. However, this procedure is technically demanding and sometimes even prohibitive because of the potential risk for vertebral artery injury.

Pars screws are an alternative method for axis fixation with less risk of vertebral artery injury ${ }^{24}$. The insertion of a C2 pars screw is similar to the posterior transarticular screw placement, using shorter length screws, with the starting point selected in the medial half of the inferior facet of C2 (2 mm up and $2 \mathrm{~mm}$ lateral to the junction of the medial portion of the $\mathrm{C} 2-\mathrm{C} 3$ facet joint $)^{20}$. Hoh et al. ${ }^{24}$ retrospectively reviewed a random selection of $50 \mathrm{CT}$ scans and evaluated various starting points and trajectories for C2 pars screws. They concluded that $99 \%$ of pars interarticularis are at least $14 \mathrm{~mm}$ in length when using a conventional transarticular screw entry point with a trajectory directed toward the superior facet-pars junction. In our series, we used pars screws lengths of 14-16 mm for maximal safety in order to avoid breaching the transverse foramen.

Considering pedicle screws, the entry point is located lateral to the superior margin of the lamina, and the trajectory for drilling the pedicle is about 20 degrees up and 15-25 degrees medially ${ }^{20}$. Preoperative CT scans are fundamental to demonstrate any rotational variations that influence the final direction. Patients with a hypoplastic pedicle do not tolerate a C2 pedicle screw ${ }^{24}$. Igarashi et al. ${ }^{25}$ selected 98 dry axis vertebrae of adult skeletons for measurement and showed that $20 \%$ of the spec- imens had a pedicle diameter smaller than $3.5 \mathrm{~mm}$, making the screw placement difficult. Because of this potential risk, pedicle screws were less used in our series.

Frequently, many studies fail to anatomically define the C2 pedicle and the pars and often combine these structures ${ }^{26}$. Elliott et al. ${ }^{27}$ reviewed a series of published papers describing C2 pars and pedicle screw implantation and demonstrated that both types can be placed accurately with low morbidity. The risk of vertebral artery injury with C2 pedicle screws was $0.3 \%$, and no injury occurred with shorter pars screws, while longer pars screws $(>16 \mathrm{~mm})$ could increase the risk of artery injury ${ }^{27}$. There was a low rate of clinically significant screw inappropriate positions for both techniques ${ }^{27}$. They also showed that $\mathrm{C} 1$ lateral mass screws combined with C2 pars or pedicle screws can provide excellent rates of stabilization without the use of halo-vest immobilization (95-99\%) ${ }^{27}$.

In the case of laminar screws, the entry point angle and direction of the drilling should match the slope of the lamina ${ }^{20}$. In this technique, the entire length of the screw is within the surgical field, making placement safer and minimizing any risk to the vertebral artery injury ${ }^{20}$. Cassinelli et al. ${ }^{22}$ studied the axis vertebrae of 420 human adult cadavers and showed that the lamina can safely accommodate screw placement in the majority of specimens. They also demonstrated gender-related differences in laminar measurements ${ }^{22}$. Laminar thickness was $8.3 \%$ smaller in women compared to men ${ }^{22}$. Interesting, there were no statistically significant differences in laminar measurements considering race, height, and weight ${ }^{22}$.

A comparison of operative morbidity, accuracy, and durability of laminar versus pedicle screw fixation of $\mathrm{C} 2$ was published by Parker et al. ${ }^{28}$. The authors divided the patients into two groups: axial and subaxial fixation ${ }^{28}$. After one year postoperatively, pseudoarthrosis or screw pullout requiring operative revision occurred in 4 (6.1\%) patients with laminar screws versus 0 patients with pedicle screws in subaxial constructions ${ }^{28}$. However, no cases of laminar or pedicle screws for axial cervical fusions required reoperation ${ }^{28}$. These findings indicate that both techniques are equally effective and safe for axial cervical fusions, while the durability of laminar screws might be inferior to pedicle screws when extended to the subaxial spine ${ }^{28}$. 


\section{CONCLUSION}

Biomechanical testing using fourteen cadaveric specimens suggested that $\mathrm{C} 2$ pedicle screws offer the strongest fixation ${ }^{29}$. Their results also demonstrate that laminar fixation is superior to pars instrumentation ${ }^{29}$. In our series, we used pedicular screws only in situations that large constructions were required, such as $\mathrm{C} 2$-thoracic fusions.
In conclusion, axis screw instrumentation was a safe and efficient method used for cervical stabilization, regardless of the technique used. The choice of the suitable fixation technique should be determined by the local anatomy, posterior element fractures or necessity to remove the posterior elements. The choice of the technique also depends on the surgeon's experience and preference.

\section{RESUMO}

OBJETIVO: Apresentar os resultados cirúrgicos de pacientes submetidos à instrumentação com parafusos do áxis, discutindo nuances cirúrgicas e complicações das técnicas utilizadas.

MÉTODOS: Série retrospectiva de pacientes submetidos à instrumentação do áxis utilizando parafusos.

RESULTADOS: Sessenta e cinco pacientes foram incluídos neste estudo. A causa mais comum de instabilidade foi trauma raquimedular envolvendo o áxis (36 pacientes - 55,4\%), seguida por malformação craniocervical congênita (12 pacientes - 18,5\%). Trinta e sete (57\%) pacientes necessitaram concomitante fusão de C1. Fixação bilateral foi realizada em quase todos os casos. Vinte e três pacientes $(35,4 \%)$ foram submetidos à fixação com parafusos de lâmina; parafusos de pars foram utilizados em 22 pacientes (33,8\%) e de pedículo, isoladamente, em três (4,6\%). Em 14 casos (21,5\%), realizamos técnicas combinadas. Não houve piora neurológica ou lesão de artéria vertebral nesta série de casos.

CONCLUSÃo: A instrumentação com parafusos do áxis foi um método seguro e eficaz para estabilização cervical. A fixação da lâmina e a da pars foram as técnicas mais utilizadas.

PALAVRAS-CHAVE: Vértebra cervical áxis. Vértebras cervicais. Parafusos ósseos. Fixadores internos.

\section{REFERENCES}

1. Joaquim AF, Patel AA. Occipto-cervical trauma: evaluation, classification and treatment. Contemp Spine Surg. 2010;11(4):1-5

2. Joaquim $A F$, Patel $A A . C 1$ and $C 2$ spine trauma: evaluation, classification and treatment. Contemp Spine Surg. 2010;11(3):1-7.

3. Patel AA. Subaxial cervical trauma: evaluation, classification, and treatment. Contemp Spine Surg. 2009;10(2):1-8.

4. Brooks AL, Jenkins EB. Atlanto-axial arthrodesis by the wedge compression method. J Bone Joint Surg Am. 1978;60(3):279-84.

5. Dickman CA, Sonntag VK. Posterior C1-C2 transarticular screw fixation for atlantoaxial arthrodesis. Neurosurgery. 1998;43(2):275-80.

6. Gallie WE. Fractures and dislocations of the cervical spine. Am J Surg 1939;46(3):495-9.

7. Aryan HE, Newman CB, Nottmeier EW, Acosta FL |r, Wang VY, Ames CP. Stabilization of the atlantoaxial complex via C-1 lateral mass and C-2 pedicle screw fixation in a multicenter clinical experience in 102 patients: modification of the Harms and Goel techniques. J Neurosurg Spine. 2008;8(3):222-9.

8. Joaquim AF, Ghizoni E, Rubino PA, Anderle DV, Tedeschi H, Rhoton Jr $A L$, et al. Lateral mass screws fixation of the atlas: surgical technique and anatomy. World Neurosurg. 2010;74(2-3):359-62.

9. Farey ID, Nadkarni S, Smith N. Modified Gallie technique versus transarticular screw fixation in C1-C2 fusion. Clin Orthop Relat Res. 1999;(359):12635.

10. Coyne TJ, Fehlings MG, Wallace MC, Bernstein M, Tator CH. C1-C2 posterior cervical fusion: long-term evaluation of results and efficacy. Neurosurgery. 1995;37(4):688-92.

11. Crisco || $3^{\text {rd }}$, Panjabi MM, Oda T, Grob D, Dvorak |. Bone graft translation of four upper cervical spine fixation techniques in a cadaveric model. J Orthop Res. 1991;9(6):835-46.

12. Grob D, Crisco J| $3^{\text {rd }}$, Panjabi MM, Wang P, Dvorak J. Biomechanical evaluation of four different posterior atlantoaxial fixation techniques. Spine (Phila Pa 1976). 1992;17(5):480-90.
13. Dickman CA, Sonntag VK, Papadopoulos SM, Hadley MN. The interspinous method of posterior atlantoaxial arthrodesis. I Neurosurg. 1991;74(2):190-8

14. Sonntag VK, Kalfas I. Innovative cervical fusion and instrumentation techniques. Clin Neurosurg. 1991;37:636-60.

15. Grob D, Jeanneret B, Aebi M, Markwalder TM. Atlanto-axial fusion with transarticular screw fixation. J Bone Joint Surg Br. 1991;73(6):972-6.

16. Magerl F, Seeman PS. Stable posterior fusion of the atlas and axis by transarticular screw fixation. In: Kehr P, Weidner A, eds. Cervical spine. Berlin: Springer; 1986. p.322-7.

17. Sherk HH, Snyder B. Posterior fusions of the upper cervical spine: indications, techniques, and prognosis. Orthop Clin North Am. 1978;9(4):1091-9.

18. Goel A, Laheri V. Plate and screw fixation for atlanto-axial subluxation. Acta Neurochir (Wien). 1994;129(1-2):47-53.

19. Lehman RA Jr, Dmitriev AE, Helgeson MD, Sasso RC, Kuklo TR, Riew KD. Salvage of $\mathrm{C} 2$ pedicle and pars screws using the intralaminar technique: a biomechanical analysis. Spine. 2008;33(9):960-5.

20. Yanni DS, Perin NI. Fixation of the axis. Neurosurgery. 2010;66(3 Suppl): $147-52$

21. Wright NM. Posterior C2 fixation using bilateral, crossing C2 laminar screws: case series and technical note. I Spinal Disord Tech. 2004;17(2):158-62

22. Cassinelli EH, Lee M, Skalak A, Ahn NU, Wright NM. Anatomic considerations for the placement of C2 laminar screws. Spine (Phila Pa 1976). 2006;31(24):2767-71.

23. Joaquim AF, Ghizoni E, Anderle DV, Oliveira E, Tedeschi H. Axis instrumentation: surgical results. Arq Neuropsiquiatr. 2012;70(11):857-63.

24. Hoh DJ, Liu CY, Wang MY. A radiographic computed tomography-based study to determine the ideal entry point, trajectory, and length for safe fixation using C-2 pars interarticularis screws. J Neurosurg Spine. 2010;12(6):602-12 
25. Igarashi T, Kikuchi S, Sato K, Kayama S, Otani K. Anatomic study of the axis for surgical planning of transarticular screw fixation. Clin Orthop Relat Res. 2003;(408):162-6.

26. Ebraheim NA, Fow J, Xu R, Yeasting RA. The location of the pedicle and pars interarticularis in the axis. Spine (Phila $\mathrm{Pa}$ 1976). 2001;26(4):E34-7.

27. Elliott RE, Tanweer O, Boah A, Smith ML, Frempong-Boadu A. Comparison of safety and stability of $\mathrm{C}-2$ pars and pedicle screws for atlantoaxial fusion: meta-analysis and review of the literature. J Neurosurg Spine. 2012;17(6):577-93.
28. Parker SL, McGirt Ml, Garcés-Ambrossi GL, Mehta VA, Sciubba DM, Witham TF, et al. Translaminar versus pedicle screw fixation of C2: comparison of surgical morbidity and accuracy of 313 consecutive screws. Neurosurgery. 2009;64(5 Suppl 2):343-8.

29. Dmitriev AE, Lehman RA Ir, Helgeson MD, Sasso RC, Kuhns C, Riew DK. Acute and long-term stability of atlantoaxial fixation methods: a biomechanical comparison of pars, pedicle, and intralaminar fixation in an intact and odontoid fracture model. Spine (Phila Pa 1976). 2009;34(4):365-70. 